\title{
PENGELOLAAN GIZI BENCANA PADA IBU HAMIL DAN IBU MENYUSUI
}

\author{
Nita Nurul Rachman ${ }^{1}$, Diyah Eka Andayani \\ ${ }^{1}$ Department of Nutrition, Faculty of Medicine Universitas Indonesia, Cipto Mangunkusumo General Hospital, \\ Jakarta, Indonesia \\ ${ }^{2}$ Department of Nutrition, Faculty of Medicine Universitas Indonesia, Cipto Mangunkusumo General Hospital, \\ Jakarta, Indonesia \\ *Corresponding author, contact : nitanurulr1@gmail.com
}

\begin{abstract}
Abstrak
Indonesia merupakan negara kepulauan yang luas dan mempunyai potensi kejadian bencana yang tinggi. Masalah kesehatan yaitu malnutrisi merupakan salah satu masalah utama dalam kondisi bencana .Rusaknya berbagai sarana dan prasarana pelayanan umum dan kesehatan, terputusnya jalur distribusi pangan dan ketersediaan pangan yang terbatas, sanitasi lingkungan yang buruk dan rusaknya sarana air bersih menjadi dasar terjadinya kekurangan asupan nutrisi pada korban terdampak bencana. Pandemik COVID-19 yang saat ini terjadi tentunya menjadi tantangan tersendiri bagi dunia kesehatan. Diperlukan perhatian khusus untuk pengelolaan gizi pada saat bencana, terutama pada ibu hamil dan ibu menyusui sebagai populasi rentan. Pengelolaan gizi tidak hanya berkaitan dengan permasalahan kesehatan pada ibu hamil dan ibu menyusui saja, tetapi menjadi kesatuan dengan dampak kesehatan yang akan terjadi pada masa depan kesehatan bayi yang akan dilahirkan. Pengetahuan akan pengelolaan gizi yang baik diharapkan dapat menurunkan angka kejadian masalah kesehatan yang terjadi pada saat bencana.
\end{abstract}

Kata kunci : gizi, bencana, malnutrisi, COVID-19

\begin{abstract}
Abstrak
Indonesia is an archipelagic country and has a high potential for disaster events. Health problems like malnutrition is one of the main problems in disaster conditions. Damage to various public and health service facilities and infrastructure, cut off food distribution lines and limited food availability, poor environmental sanitation and damage to basic clean water facilities resulting in a lack of nutritional intake for disaster victim. The current COVID-19 pandemic is certainly a challenge for the health world. Particular attention should be paid to nutrition management in times of disaster, especially for pregnant women and breastfeeding mothers as vulnerable populations. Nutrition management is not only related to health problems for pregnant women and breastfeeding mothers, but is integrated with the health impacts that will occur in the future health of babies to be born. Knowledge of good nutrition management is expected to reduce the incidence of health problems that occur during disasters.
\end{abstract}

Keywords: nutrition, disaster, malnutrition, COVID-19

\section{Pendahuluan}

Indonesia merupakan negara dengan wilayah geografis yang luas dan demografis yang beragam. Kondisi ini membuat Indonesia memiliki kerentanan lebih terhadap terjadinya berbagai bencana alam. ${ }^{1}$
Berdasarkan data infografis Badan Nasional Penanggulangan Bencana (BNBP) jumlah total bencana di Indonesia sepanjang tahun 2020 mencapai 2.952 kasus bencana. Pada awal tahun 2020 Indonesia juga dikejutkan dengan bencana non alam yang berasal dari 
bencana kesehatan berupa coronavirus diseases 19 (COVID - 19) yang merupakan pandemik global yang menyebar keseluruh dunia termasuk Indonesia. $^{2}$ Terdapat 2.670.046 orang terkonfirmasi COVID-19 di Indonesia, terdiri dari 443.473 kasus aktif dan 69.210 orang diantaranya meninggal dunia (data per tanggal 14 Juli 2021). ${ }^{3}$ Data yang dikumpulkan oleh Persatuan Obstetri dan Ginekologi Indonesia (POGI) menunjukkan 536 kasus COVID-19 terjadi pada ibu hamil selama bulan April 2020 - April 2021, diantaranya sebanyak $72 \%$ terjadi pada usia kehamilan di atas 37 minggu. ${ }^{4}$ Pandemi COVID-19 bersama dengan tingginya angka kejadian bencana alam di Indonesia memperburuk situasi terutama dalam bidang gizi masyarakat yang berkaitan erat dengan tingkat kesehatan masyarakat terdampak bencana. $^{2}$

Penurunan status kesehatan yang berasal dari infeksi menular dan penurunan status gizi menjadi masalah pokok yang umumnya terjadi pada kondisi kedaruratan bencana. ${ }^{5}$ Dampak kesehatan ini dapat mengubah fungsi dan kualitas hidup masyarakat terdampak bencana. ${ }^{6}$ Permasalahan kesehatan dan status gizi terjadi pada seluruh kelompok masyarakat, terutama kelompok rentan seperti bayi, balita, ibu hamil,ibu menyusui dan lanjut usia. ${ }^{7}$ Ibu hamil dan ibu menyusui yang kekurangan asupan pada saat bencana menimbulkan potensi kejadian infeksi, stunting dan malnutrisi pada bayi dan anak dikemudian hari. Pada ibu hamil yang kekurangan gizi memiliki potensi tinggi untuk persalinan prematur, melahirkan bayi dengan berat badan lahir rendah bahkan kematian bagi ibu dan anak sehingga menjadi ancaman kesehatan yang nyata $4,5,8$

Dasar timbulnya dampak kesehatan dan gizi pada saat bencana adalah rusaknya berbagai sarana dan prasarana pelayanan umum dan kesehatan. Terputusnya jalur distribusi pangan dan ketersediaan pangan yang terbatas, sanitasi lingkungan yang buruk dan rusaknya sarana air bersih menjadikan dasar bagi permasalahan kesehatan akibat bencana. ${ }^{9}$ Keseluruhan hal ini merupakan tantangan yang harus dihadapi agar penilaian kebutuhan gizi yang cepat pada korban terdampak dan pengelolaan gizi bencana yang efisien dapat terlaksana dengan baik. Pengelolaan gizi yang cepat dan tepat tentunya akan membuat permasalahan kesehatan seperti kekurangan asupan nutrisi ataupun infeksi dapat terkendali dengan baik, sehingga tidak menimbulkan efek penyakit berat yang berkelanjutan.

Penanganan tanggap darurat bencana yang komprehensif terkadang terkendala dengan derajat dan luasnya keparahan bencana. Situasi ini diperburuk dengan 
pengetahuan masyarakat yang masih terbatas terhadap situasi darurat bencana.dan pandemik COVID-19 5, 10 Intervensi gizi merupakan hal yang esensial terutama pada masa tanggap darurat awal agar masyarakat tidak mengalami situasi kelaparan dan terjadi penurunan status gizi terutama pada populasi rentan. ${ }^{11}$ Penanganan gizi lanjutan tetap diperlukan mengingat efek samping status gizi kurang dapat memberikan efek jangka panjang pada status kesehatan dan ekonomi populasi terdampak. ${ }^{12}$ Oleh karena itu pengetahuan dan penerapan tentang manajemen pengelolaan kesehatan terutama gizi yang baik diperlukan untuk pemenuhan status gizi penyintas bencana dan perlu menjadi perhatian dari berbagai pihak.

\section{Siklus Bencana}

Siklus bencana (gambar 1) seperti sebuah lingkaran yang saling berhubungan satu sama lain. Siklus bencana dapat dibagi menjadi tiga fase siklus yaitu fase pra bencana, fase bencana dan fase paska bencana. ${ }^{13}$ Penanganan bencana tidak hanya dimulai setelah terjadi suatu bencana, dengan kemajuan teknologi kita dapat memprediksikan terjadinya suatu bencana sehingga dapat melakukan tindakan penanggulangan sebelum terjadinya potensi bencana pada suatu daerah. Kegiatan yang termasuk ke dalam fase pra bencana yaitu kegiatan pencegahan(prevention), mitigasi (mitigation) dan kesiapsiagaan (preparedness).$^{13}$ Kegiatan pra bencana diterapkan untuk mengurangi potensi kerugian pada masyarakat, baik kesehatan maupun harta benda. Sebagai contoh dilakukannya kampanye kesadaran potensi bencana di daerah masing-masing , memperkuat struktur fasilitas umum, transportasi dan kesehatan, pelatihan tanggap darurat bencana di tingkat rumah tangga dan masyarakat. Langkah-langkah pengurangan risiko tersebut diambil di bawah tahap yang disebut sebagai kegiatan mitigasi dan kesiapsiagaan. ${ }^{14,15}$

Fase bencana atau disebut juga fase tanggap darurat merupakan kegiatan yang memastikan bahwa kebutuhan bagi masyarakat terdampak bencana terpenuhi dan meminimalisir kerugian akibat bencana. ${ }^{14}$ Fase tanggap darurat adalah fase dimana dilakukan berbagai aksi darurat yang nyata untuk menjaga keutuhan diri sendiri, sumber daya dan harta kekayaan. Pada fase ini muncul permasalahan kesehatan selama dalam pengungsian seperti kelaparan, infeksi menular, penurunan status gizi, masalah higienitas, ketersediaan air dan obat-obatan ${ }^{14}$ Fase paska bencana terdiri dari pemulihan (relief), rekontruksi dan rehabilitasi. Saat keadaan darurat telah dikendalikan, penduduk yang terkena 
dampak diharapkan mampu melakukan semakin banyak kegiatan yang bertujuan memulihkan kehidupan menuju normal dan perbaikan infrastruktur berkala. Proses pemulihan mungkin terjadi lambat, hal ini tergantung dengan kapasitas suatu negara sebagai elemen kunci dalam melakukan penanggulangan darurat bencana. ${ }^{16}$ Tidak ada titik yang jelas di mana fase tanggap darurat segera berubah menjadi fase pemulihan dan kemudian membaik menuju pembangunan berkelanjutan jangka panjang. Rehabilitasi dan rekonstruksi fisik terkadang dapat berlangsung lebih cepat dibandingkan rehabilitasi sosial atau psikologis. ${ }^{14,15}$

\section{Masalah Gizi Pada Golongan Rentan Saat Bencana}

Pada keadaan bencana, semua orang memiliki risiko untuk mendapatkan masalah kesehatan, tetapi pada beberapa kelompok masyarakat terdapat kerentanan lebih yang disebut dengan populasi rentan, ibu hamil dan ibu menyusui termasuk ke dalam populasi tersebut. $^{5,} 11$ Kejadian kekurangan gizi, malnutrisi dan infeksi menular menjadi permasalahan penting yang paling sering menjadi perhatian pada saat terjadi bencana. ${ }^{5}$

Kondisi nutrisi pada saat konsepsi dan selama kehamilan penting untuk kesehatan ibu dan anak. ${ }^{17}$ Kekurangan nutrisi dan peningkatan risiko kejadian infeksi pada ibu hamil akibat bencana menimbulkan keterhambatan perkembangan bayi di kemudian hari. Bayi yang lahir dari ibu yang kurang nutrisi cenderung memiliki risiko lahir dengan keadaan dan perkembangan yag kurang baik di masa depan misalnya berat badan lahir rendah, stunting ataupun keterlambatan mental. ${ }^{5,7}$ Kurang tersedianya suplementasi untuk ibu hamil pada saat bencana contohnya tablet asam folat dapat meningkatkan risiko kelainan saraf pada bayi. ${ }^{17}$ Kekurangan nutrisi pada ibu menyusui saat bencana memberikan dampak kepada penurunan ASI. WHO memperkirakan bahwa malnutrisi adalah penyebab mendasar dilebih dari setengah kematian pada anak. ${ }^{8}$ Hal ini tentunya menjadi satu kesatuan dengan terjadinya peningkatan risiko malnutrisi pada bayi akibat kurangnya produksi ASI pada ibu menyusui yang mengalami kekurangan asupan ataupun terkena infeksi menular saat bencana, serta kurangnya edukasi terhadap cara menyusui dan fungsi ASI bagi kehidupan anak. ${ }^{5,11}$

Kelangsungan risiko kesehatan yang tinggi pada ibu hamil dan menyusui tidak hanya disebabkan oleh pola makan yang tidak memadai dan/atau tidak seimbang, tetapi juga dikarenakan wabah penyakit yang dapat terjadi di wilayah bencana terutama di daerah evakuasi/pengungsian yang padat populasi. ${ }^{8}$ Sanitasi dan higienitas yang kurang baik 
menjadikan kejadian infeksi meningkat. Beberapa contoh penyakit yang dapat terjadi adalah diare, muntah, infeksi saluran pernapasan, infeksi menular (campak, tuberkulosis, malaria, HIV/AIDS) ataupun leptospirosis. 5,8 Tingkat kematian dari populasi pengungsi dapat mencapai sepuluh kali lipat lebih tinggi dibandingkan populasi yang sama dalam keadaan tidak darurat. Angka kematian yang luar biasa tinggi ini didapatkan selama beberapa bulan pertama ketika mengungsi. ${ }^{8}$

Pada saat kegawatdaruratan bencana, ibu hamil banyak mengalami penurunan status gizi, terlepas dari faktor asupan yang memang berkurang hal ini diperburuk dengan faktor stress yang meningkat pada saat bencana. $^{6,} 11$ Ibu yang kurang nutrisi akan melahirkan bayi yang kecil dengan berat badan lahir rendah (BBLR) dan memiliki tingkat mortalitas lebih tinggi baik bagi bayi atau ketika proses melahirkan. ${ }^{6,7}$ Bayi BBLR cenderung akan mengalami kejadian stunting, tumbuh kurus (wasted) ataupun mengalami gangguan perkembangan saraf di masa depan. ${ }^{6}$

Kebutuhan nutrisi mikronutrien bagi keseluruhan populasi juga mengalami penurunan yang tinggi. Asupan yang kurang disertai ketidakberagaman nutrisi yang didapat menjadikan kekurangan mikronutrien cenderung meningkat. ${ }^{6}$, 11 Tiga masalah defisiensi mikronutrien tersering saat bencana adalah defisiensi vitamin A, zat besi dan iodium. $^{7}$ Data dari WHO WHO mengidentifikasi ibu hamil merupakan populasi berisiko mengalami defisiensi vitamin A berdasarkan data prevalensi rabun senja terjadi pada 5\% ibu hamil. Pemberian suplementasi vitamin A direkomendasikan terutama pada ibu hamil di negara berkembang yang kemungkinan memiliki keterbatasan dalam menerima asupan gizi yang baik selama kehamilan. Anemia karena zat besi paling umum terjadi pada anak-anak (usia 6-24 bulan) dan wanita usia reproduksi (terutama wanita hamil). ${ }^{6}$ Hasil riset kesehatan dasar (Riskesdas) 2018 menunjukkan bahwa sebesar $48.9 \%$ ibu hamil mengalami anemia. Sejumlah $84.6 \%$ ibu hamil yang mengalami anemia berada pada kelompok umur 15-24 tahun. ${ }^{18}$ Anemia pada ibu hamil sebagian besar merupakan akibat dari kekurangan zat besi, sehingga pemberian suplementasi zat besi penting terutama pada masa subur dan masa kehamilan. Menurut data dari Riskesdas 2018 angka cakupan pemberian zat besi pada ibu hamil sebesar $73.2 \%$. Berdasarkan jumlah tersebut hanya $24 \%$ ibu hamil yang mendapatkan jumlah tablet tambah besi yang sesuai dengan rekomendasi yaitu sejumlah $\geq 90$ tablet. Kondisi anemia ini tentunya menjadi perhatian khusus terutama pada 
bidang gizi. Hal ini disebabkan anemia berkembang perlahan dan tidak terlihat secara klinis sampai menjadi kondisi penyakit yang parah, meskipun ada konsekuensi fungsional sebelum munculnya tahap ini. ${ }^{5,7}$ Pada wanita hamil defisiensi besi menyebabkan peningkatan risiko bayi berat lahir rendah,, kematian perinatal dan kematian ibu. Pada semua individu, defisiensi besi menyebabkan penurunan kapasitas kerja dan gangguan kognisi. ${ }^{6}$ Ibu hamil seharusnya mendapatkan suplementasi besi dan asam folat setidaknya selama 6 bulan ketika kehamilan dimulai.

\section{Kekurangan/defisiensi iodium} merupakan salah satu penyakit geografis, yang terjadi di sebagian besar negara berkembang. Hal ini terjadi terutama pada daerah di mana tanahnya miskin iodium dan kandungan iodium dari makanan yang rendah, mengakibatkan asupan iodium rendah dalam populasi. Anak kecil dan wanita hamil adalah yang paling rentan terhadap kekurangan iodium. Data mengenai kekurangan iodium pada ibu hamil dan menyusui memang belum didapatkan secara pasti di Indonesia. Salah satu upaya yang telah dilakukan untuk menanggulangi kekurangan akibat iodium iodisasi atau penambahan/fortifikasi iodium pada semua garam (Universal Salt Iodization/USI). rumah tangga . Pencapaian cakupan pemberian garam beriodium di Indonesia pada tahun 2013 mencapai $77.1 \%$. Cakupan ini masih di bawah standar USI yang ditetapkan oleh WHO yaitu $90 \% .^{19}$ Kekurangan iodium dapat menyebabkan lahir mati dan keguguran pada ibu hamil serta berbagai tingkat keterbelakangan mental dan tentunya penyakit gondok. ${ }^{8}$ Penyakit lainnya yang dapat muncul akibat defisiensi mikronutrien adalah skurvi (vitamin $\mathrm{C}$ ), pellagra (niasin) dan beri-beri (tiamin). Kebutuhan akan mikronutrien terkadang luput dari perhatian, padahal hal ini akan berkontribusi baik terhadap tingkat kesehatan populasi terdampak bencana. ${ }^{7}$

\section{Pengkajian Dan Surveilans Status Gizi Pada Ibu Hamil dan Menyusui (Assessment And Surveilance)}

Selama keadaan darurat gizi,terutama pada fase awal kedaruratan akan terjadi kelangkaan bantuan makanan. Hal ini bisa disebabkan oleh distribusi bantuan yang belum bisa berjalan secara maksimal, sehingga pada fase awal bencana bantuan makanan perlu diberikan secara istimewa atau ditargetkan kepada orang-orang yang paling membutuhkan. Program bantuan makanan harus direncanakan dan dilaksanakan berdasarkan penilaian nutrisi awal yang cepat diikuti dengan survei sistematis dan pemantauan berkelanjutan (surveilans) tentang kondisi nutrisi yang 
tepat. ${ }^{6}$ Status gizi balita dapat dijadikan sebagai gambaran dan indikator yang baik dari situasi gizi secara keseluruhan di sebagian besar masyarakat. Sedangkan gambaran status gizi pada dewasa tidak terlalu mencerminkan kegawatdaruratan gizi di suatu daerah. ${ }^{6,8}$ Berbagai indikator dapat digunakan untuk menilai status gizi pada populasi ibu hamil dan menyusui.

- Indeks massa tubuh, digunakan untuk menilai status gizi orang dewasa termasuk ibu menyusui. ${ }^{6}$

- Lingkar lengan atas (LiLA) dapat digunakan sebagai metode alternatif skrining awal. Metode ini terutama dapat digunakan pada populasi ibu hamil. Ibu hamil dengan LiLA $<23.5 \mathrm{~cm}$ mengindikasikan kejadian kurang energi protein pada populasi tersebut. ${ }^{5,6}$

Penetapan jenis kegiatan pengelolaan gizi mempertimbangkan hasil dari surveilans antropometri dan penyulit. ${ }^{8,11}$ Rekomendasi yang didapatkan dari hasil survey antropometri dan penyulit (aggravating factor), yaitu :

- Situasi serius, yaitu prevalensi balita malnutrisi akut $\geq 15 \%$ tanpa faktor penyulit atau $10-14.9 \%$ dengan faktor penyulit. Semua terdampak bencana pada situasi ini mendapat ransum, keseluruhan kelompok rentan utamanya balita dan ibu hamil diberikan makanan tambahan (blanket supplementary feeding).

- Situasi berisiko, jika prevalensi balita malnutrisi akut 10-14.9\% tanpa faktor penyulit atau 5-9.9\% dengan faktor penyulit. Pada kelompok rentan terutama balita malnutrisi dan ibu hamil dengan risiko kurang energi protein diberikan makanan tambahan (targeted supplementary feeding).

- Situasi normal, prevalensi balita malnutrisi akut $<10 \%$ tanpa faktor penyulit atau $<5 \%$ dengan faktor penyulit. Dilakukan pengelolaan pada penderita gizi kurang berupa pelayanan kesehatan rutin. $5,6,8,11$

Poin yang termasuk kepada faktor penyulit adalah kerawanan pangan rumah tangga/ rata-rata asupan makanan harian kurang dari 2.100 kkal, prevalensi HIV/AIDS yang tinggi, angka kematian kasar lebih besar dari 1/10,000/hari, angka kematian kasar balita lebih besar dari 2/10.000/hari, terdapat wabah campak atau batuk rejan (pertusis), tingginya prevalensi infeksi saluran pernapasan atas atau diare dan tingginya prevalensi malnutrisi yang sudah ada sebelumnya, misalnya stunting. ${ }^{8,11}$ 


\section{Ruang Lingkup Kegiatan Gizi Dalam Berbagai Fase Bencana}

\section{A. Pra Bencana}

Program gizi yang dilakukan diantaranya yaitu program pelatihan, pembinaan teknis dan pendampingan tentang manajemen gizi bencana kepada petugas kesehatan dan petugas pelaksana kegawatdaruratan. Sosialisasi kebutuhan gizi pada saat kegawatdaruratan bencana, konseling menyusui, konseling makanan pendamping air susu ibu (MP-ASI). Pengelolaan gizi pada pra bencana secara keseluruhan bertujuan untuk mengantisipasi terjadinya bencana serta mengurangi risiko akibat dampak bencana. ${ }^{11}$

\section{B. Tanggap Darurat Bencana}

Pada masa terjadinya bencana dibagi menjadi siaga darurat, tanggap darurat dan transisi darurat. ${ }^{11}$

\section{a. Siaga Darurat}

Kondisi pergerakan pengungsi dan sumber daya. Penanganan gizi menyesuaikan situasi. ${ }^{11}$

\section{b. Tanggap Darurat}

Tahap tanggap darurat dibagi menjadi tahap tanggap darurat awal (fase I dan II) dan tahap darurat lanjut. ${ }^{7,11}$

\section{- Fase I Tahap Darurat Awal}

Perencanaan awal jumlah untuk energi digunakan dan disesuaikan dengan informasi yang tersedia di awal kedaruratan serta angka kebutuhan umum pada populasi.Pemberian makanan pada fase ini mempertimbangkan standar ransum pada populasi dan rapid health ssessment (RHA). Petugas harus memastikan bahawa ransum mencakup energi, protein, lemak dan mikronutrient yang cukup untuk memenuhi kebutuhan nutrisi dari semua sub-kelompok populasi. Jenis ransum tersedia dalam bentuk basah dan kering. Bahan-bahan makanan terfortivikasi dapat ditambahkan pada ransum. Lama fase I maksimal tiga hari setelah kejadian bencana. Pada fase ini korban berdatangan ke pengungsian dan petugas tanggap darurat belum bisa mengindentifikasi secara penuh korban bencana. Pada fase ini tujuan pemberian makanan adalah mencegah kelaparan dan sebisa mungkin mempertahankan status gizi. ${ }^{7,11}$

Jumlah kalori yang terdapat pada ransum bencana harus memenuhi $2.100 \mathrm{kkal}$ per orang per hari. Kebutuhan energi yang dibutuhkan tentunya berbeda pada berbagai kelompok populasi hal ini bergantung dengan usia, jenis kelamin, berat badan dan tingkat aktivitas fisik. ${ }^{7}$ Energi rata-rata kebutuhan per kapita suatu populasi dihitung dengan mengambil rata-rata berat badan untuk setiap kelompok umur-jenis kelamin.Perkiraan $2.100 \mathrm{kkal} /$ orang/hari juga dirancang untuk dapat memenuhi kebutuhan ibu hamil dan wanita menyusui. ${ }^{6,7}$ Formula energi 2.100 
kkal ini harus memenuhi komposisi setidaknya protein $50 \mathrm{~g}(10 \%)$ dan $40 \mathrm{~g}$ (17\%) lemak , serta mengandung zat mikronutrien baik dari bahan makanan maupun fortivikasi. Tujuan pemberian kalori ini untuk mencegah terjadinya kelaparan dan menjaga status gizi Perkiraan 2.100 kkal/orang/hari juga dirancang untuk dapat memenuhi kebutuhan ibu hamil dan wanita menyusui. Penentuan formula ini sudah melalui konsesus yang ditetapkan dalam MoU antara UNCHR/WFP dan diterapkan secara global. ${ }^{7}$ Distribusi makanan yang memadai dan tepat waktu memberikan peran penting dalam menurunkan angka penurunan status kesehatan. ${ }^{11}$

- Fase II Tahap Darurat Awal

Sudah terdapat informasi yang lebih baik tentang kondisi pengungsi/status kesehatan (umur, jenis kelamin, penyakit ) secara keseluruhan pada terdampak bencana. ${ }^{11}$ Pada fase ini angka perencanaan awal untuk energi direvisi dan dinilai ulang lebih lanjut berdasarkan perubahan keadaan selama periode bencana. $^{7}$

Pengelolaan gizi yang dilakukan pada fase ini meliputi survey dan pengumpulan data antropometri, penilaian proporsi status gizi balita yaitu gizi kurang dan gizi buruk, penilaian risiko kurang energi protein pada ibu hamil berdasarkan LiLA, analisis dan penilaian risiko penyulit contohnya infeksi , serta pemberian tambahan makanan dan suplementasi . ${ }^{11}$ Penetapan jenis kegiatan pengelolaan gizi seperti yang telah dijelaskan sebelumnya mempertimbangkan hasil dari surveilans antropometri dan penyulit (aggravating factor). ${ }^{8,11}$

c. Transisi Darurat

Merupakan kondisi peralihan/transisi sebelum dilakukan rehabilitasi dan rekonstruksi. Kegiatan pengelolaan gizi disesuaikan dengan situasi dan kondisi yang ada. $^{11}$

\section{Paska Bencana}

Program gizi meliputi pemantauan dan evaluasi yang merupakan bagian dari surveilans,. Hal ini dilakukan untuk mengetahui seberapa besar kebutuhan yang diperlukan pada korban dan daerah terdampak. Kegiatan pembinaan gizi berkelanjutan dilakukan dengan berkoordinasi dengan kegiatan pelayanan kesehatan setempat,hal ini merupakan upaya tindak lanjut dalam meningkatkan dan mempertahankan status gizi dan kesehatan pada korban terdampak bencana. $5,8,11$

\section{Tatalaksana Gizi Saat Bencana dan COVID-19}

Tatalaksana kegiatan gizi pada saat bencana harus dilakukan secara efektif dan efisien, serta diperlukan koordinasi dari 
berbagai pihak diantaranya dibutuhkan untuk:

- Penyusunan menu untuk kebutuhan kelompok rentan.

- Kalkulasi kebutuhan ransum.

- Penyusunan menu ransum 2.100 kkal dengan komposisis $50 \mathrm{~g}$ protein dan $40 \mathrm{~g}$ lemak.

- Pemberian suplementasi mikronutrien, contoh tablet besi pada ibu hamil dan kapsul vitamin untuk balita dan ibu hamil.

- Penyelenggaraan, pendampingan, pengawasan logistik dimulai dari

- Persiapan sampai pendistribusian termasuk bantuan susu formula dari pihak luar.

- Pelaksanaan, pemantauan dan indak lanjut surveilans gizi.

- Pengadaan konseling gizi terutama konseling tentang menyusui dan

- Konseling MP-ASI. ${ }^{6-8,11}$

Penanganan gizi pada saat bencana di populasi rentan tentunya memerlukan perhatian khusus. Pada populasi ibu hamil diperlukan penambahan energi sebesar 285 kkal dan $17 \mathrm{~g}$ protein per hari untuk ibu hamil. Pada ibu menyusui dibutuhkan penambahan energi sebesar 500 kkal dan 17 $\mathrm{g}$ protein per hari. Dilakukan pemberian tablet tambah darah pada ibu hamil selama 90 hari (tablet besi $60 \mathrm{mg} /$ hari, asam folat 400 mg/hari). ${ }^{7,} 11$ Pemberian 2 kapsul vitamin A (1 kapsul pada hari pertama dan 1 kapsul di hari berikutnya) dengan dosis 200.000 IU pada ibu nifas (0-42 hari). ${ }^{11}$ Manajemen profilaksis anti instestinal parasit dapat diberikan pada ibu hamil berupa $500 \mathrm{mg}$ mebendazole di trimester kedua dan ketiga. Perlu dipastikan ibu hamil dan ibu menyusui mendapatkan akses terhadap air minum yang bersih. $^{7}$ Dilakukan pemberian penyuluhan tentang gizi baik secara kelompok maupun perorangan sesuai dengan kondisi saat itu, sebagai contoh konseling tentang MP-ASI ${ }^{7}$, 11

Pandemi COVID-19 disertai dengan kejadian bencana di suatu daerah akan meningkatkan risiko lebih tinggi terjadinya penularan secara cepat infeksi COVID-19 kepada korban bencana. Terjadi ketidakseimbangan energi pada tubuh penderita COVID-19 yaitu perubahan metabolisme berupa peningkatan katabolisme diakibatkan inflamasi yang dapat menyebabkan terjadinya keseimbangan energi negatif. ${ }^{20} \mathrm{Hal}$ ini dapat menimbulkan masalah gizi akut dan penurunan daya tahan tubuh terutama pada kelompok rentan, yang dapat berujung kepada peningkatan risiko kematian. ${ }^{20,21}$

Pada saat bencana penyebaran infeksi akibat COVID-19 sulit dihindari terutama pada fase awal tanggap darurat, hal ini 
disebabkan kondisi yang tidak memungkinkan untuk menjaga protokol kesehatan yang baik seperti memakai masker, menjaga jarak ataupun tidak membuat kerumunan. Diperlukan skrining COVID-19 berskala masif pada seluruh korban bencana yang responsif sehingga petugas bencana dapat bertindak cepat untuk memilah pasien yang harus dilakukan isolasi, sehingga diharapkan dapat meminimalisir penyebaran COVID-19. Skrining juga memiliki kegunaan agar pasien terkonfirmasi atau belum terkonfirmasi dengan penyakit komorbid, ataupun dengan gejala sedangberat yang memerlukan pengawasan lebih agar dapat segera dilakukan tindakan rujukan ke fasilitas kesehatan yang lebih mumpuni. ${ }^{22}$ Tempat pengungsian dapat menangani pasien COVID-19 tanpa gejala dan dengan gejala ringan meskipun tidak sepenuhnya ideal dan memerlukan pengawasan dari tenaga kesehatan yang ketat.

Penanganan gizi tentunya harus menerapkan protokol pencegahan infeksi COVID-19 yang baik dengan cara memakai alat pelindung diri (APD) yang baik sesuai dengan zona yang ditetapkan, membatasi waktu pemeriksaan/konseling maksimal 15 menit, pemeriksaan dilakukan pada ruangan dengan cukup ventilasi dan menjaga jarak fisik setidaknya 1-2 meter. $^{21}$
Pemberian kebutuhan energi pada pasien dewasa COVID-19 dapat diberikan berdasarkan status gizi, kondisi klinis , pemeriksaan penunjang, dan hemodinamik dan penyakit komorbid . Energi dapat diberikan sejumlah 30-35 kkal/kg BB/hari dengan komposisi karbohidrat 50-60\%, protein 1.2-2 g/kg BB/hari , 15-25\% dan lemak $25-30 \%$ dari total energi harian. Hal ini menjadi tantangan karena secara jumlah energi pada ransum tahap I memang sudah memenuhi tetapi secara komposisi masih kurang dibandingkan dengan yang dianjurkan pada pasien COVID-19. Sehingga perlu pembangunan dapur umum secara segera (kurang dari 5 hari) di tempat bencana agar pengelolaan gizi dapat lebih terprogram dengan baik. Pemberian vitamin dan mineral dapat mengikuti panduan praktis penatalaksanaan nutrisi COVID-19 yang telah dikeluarkan oleh Perhimpunan Dokter Spesialis Gizi Klinik Indonesia (PDGKI). ${ }^{20}$

Pengelolaan gizi pada kelompok rentan membutuhkan perhatian khusus, terutama dengan adanya pandemik COVID19 menjadikan kelompok rentan berisiko tinggi untuk terpapar dan mendapatkan derajat penyakit yang lebih parah. Ibu hamil memiliki risiko tinggi mengalami anemia akibat peningkatan volume darah , pembentukan plasenta dan cadangan zat besi pada ASI. Pada pasien ibu hamil dengan 
suspek maupun terkonfirmasi COVID-19, pemberian tablet besi dapat ditunda , kelanjutan pemberian tablet besi menyesuaikan dengan kondisi klinis dari pasien. ${ }^{17,18}$ Pemberian mikronutrien tambahan sesuai dengan protokol tatalaksana COVID-19 dapat diberikan pada ibu hamil yang terkonfirmasi COVID-19 berupa vitamin $\mathrm{C}, \mathrm{D}, \mathrm{E}$ dan seng. Vitamin $\mathrm{C}$ non acidic diberikan per oral dengan dosis 500 mg/6-8 jam untuk 14 hari, tablet hisap vitamin C $500 \mathrm{mg} / 12$ jam diberikan dalam 30 hari serta vitamin D dosis 1000-5000 internasional unit/hari. ${ }^{18}$ Pengawasan peningkatan berat badan normal sesuai dengan kenaikan trimester kehamilan tetap dilakukan secara berkala. ${ }^{20,17}$

Pada ibu menyusui terkonfirmasi positif COVID-19 tetap dapat memberikan ASI pada bayi dengan melakukan protokol pencegahan penularan COVID-19 yang ketat. Jika ibu tidak dapat menyusui secara langsung, ibu dapat memerah ASI . Selanjutnya ASI perah diberikan kepada bayi melalui orang yang sehat. Tenaga kesehatan dapat memberikan konseling cara menyusui dan memerah ASI dengan protokol kesehatan yang baik . Dianjurkan memerah ASI dengan menggunakan tangan, jika memakai pompa ASI peralatan yang digunakan harus segera dibersihkan/disterilkan. ${ }^{21,22}$

\section{Monitoring Dan Evaluasi}

Monitoring dan evaluasi dilakukan dari mulai kegiatan pra bencana , tanggap darurat bencana sampai paska bencana. ${ }^{7}$ Kegiatan ini dilakukan oleh tim pengelola kegiatan gizi bersama koordinasi dari tim PPKK Kementerian Kesehatan sesuai instrument yang telah ditetapkan. ${ }^{11}$ Pada pra bencana monitoring dan evaluasi meliputi ketersediaan pedoman gizi pada saat kejadian bencana, sosialiasi dan pelatihan petugas, ketersediaan data awal untuk daerah bencana dan pembinaan antisipasi bencana. ${ }^{7,11}$ Pada masa tanggap darurat bencana meliputi ketersediaan data sasaran berdasarkan Rapid Health Assessment (RHA), ketersediaan data antropometri serta LiLA pada populasi rentan, ketersediaan makanan dan nutrisi lainnya seperti suplementasi vitamin dan mineral, pemantauan pelaksanaan kegiatan konseling pada korban bencana. ${ }^{7,8,11}$ Pada paska bencana monitoring dan evaluasi meliputi ketersediaan pembinaan teknis paska bencana pada pelayanan daerah setempat, ketersediaan analisis kebutuhan gizi (need assessment) yang diperlukan paska bencana dan perbandingan data gizi sebelum dan paska bencana contohnya kenaikan berat badan pada ibu hamil dan menyusui. Hal ini dilakukan untuk menilai keberhasilan program gizi sehingga dapat menentukan tindak lanjut kedepannya terhadap korban 
bencana tersebut. ${ }^{7,} 11$ Pada saat bencana dan pandemik COVID-1 monitoring dan evaluasi secara umum yang dapat dilakukan adalah mencakup penilaian kondisi pasien, pelacakan (tracing) pada individu yang melakukan kontak erat dengan pasien COVID-19 serta memastikan tidak terjadi penyebaran yang lebih luas dengan cara prosedur isolasi pasien dan protokol pencegahan infeksi sesuai yang tercantum pada protokol tata laksana COVID-19. ${ }^{22}$ Pada masa kegawatdaruratan bagian gizi memastikan pada saat isolasi pasien COVID19 tetap mendapatkan asupan nutrisi yang baik sesuai dengan kebutuhan dan kondisi pasien, hal ini bisa dilakukan dengan melakukan anamnesis asupan pasien (pencapaian target nutrisi), penilaian hemodinamik, tanda vital dan melakukan pengukuran antropometri berkala dengan tetap menjaga protokol pencegahan infeksi yang baik. ${ }^{20}$

\section{Kesimpulan dan saran}

Pengelolaan gizi merupakan bagian penting dalam pelaksanaan kegiatan penanggulangan bencana disetiap siklus bencana.. Masalah utama kesehatan yang dapat muncul pada saat bencana berupa penurunan status gizi, defisiensi makronutrien, mikronutrien dan infeksi menular. Pandemik COVID-19 disertai dengan kejadian bencana di suatu daerah akan meningkatkan risiko lebih tinggi terjadinya penularan secara cepat infeksi COVID-19 kepada korban bencana. Pengelolaan gizi pada kelompok rentan membutuhkan perhatian khusus, terutama dengan adanya pandemik COVID-19 menjadikan kelompok rentan berisiko tinggi untuk terpapar dan mendapatkan derajat penyakit yang lebih parah dan akhirnya meningkatkan risiko kematian. Pengelolaan gizi yang tidak baik pada ibu hamil dan ibu menyusui tidak hanya berdampak pada individu tersebut melainkan akan memberikan efek kesehatan yang buruk pula pada bayi yang dilahirkan serta masa depan perkembangan anak. Permasalahan kesehatan yang berkelanjutan juga akan menimbulkan beban ekonomi dan sosial bagi masyarakat dan negara.

Masih terbatasnya pengetahuan tentang COVID-19 disertai kondisi pandemik yang masih terus berkembang menjadikan tantangan tersendiri dalam pengelolaan gizi terutama dalam memberikan nutrisi yang tepat bagi penderita COVID-19. Hal ini ditambah dengan kurang tersedianya informasi, pelatihan serta pencegahan pra bencana yang belum merata di tiap daerah menjadikan tindakan tanggap darurat ketika terjadi bencana menjadi lebih sulit. Permasalahan mengenai distribusi, 
pengolahan dan ketersediaan makanan yang cepat dan tepat seringkali menjadi masalah dalam pengelolaan gizi bencana. Perlu dilibatkan dokter spesialis gizi klinik sebagai tenaga ahli gizi dalam penulisan program kebijakan dan pedoman tatalaksana gizi pada bencana. Diperlukan koordinasi ,dukungan dan partisipasi dari berbagai pihak agar kegiatan penanggulangan bencana dapat terlaksana dengan baik.

\section{Konflik Kepentingan}

Para penulis mendeklarasikan bahwa tidak terdapat konflik kepentingan apapun terkait studi pada naskah ini.

\section{Kontribusi Penulis}

Penulis 1 - mengembangkan proposal penelitian, pengumpulan data, analisis data, dan publikasi

Penulis 2 - mengembangkan proposal penelitian dan mengumpulkan data

\section{Daftar Referensi}

1. Badan Nasional Penanggulangan Bencana. Buku saku tanggap tangkas tangguh menghadapi bencana. Jakarta: Pusat Data Informasi dan Humas Badan Nasional Penanggulangan Bencana, 2017.

2. Badan Nasional Penanggulangan Bencana. Infografis bencana Indonesia 2020. https://bnpb.go.id/infografis/infografisbencana-indonesia-2020 (diakses 6 Juni 2021)

3. Komite Penanganan COVID-19 Dan Pemulihan Ekonomi Nasional. Peta sebaran COVID-19. https://covid19.go.id. (diakses 15 Juli 2021).

4. Perkumpulan Obstetri Dan Ginekologi Indonesia. Revisi rekomendasi POGI terkait dengan melonjaknya kasus ibu hamil dengan COVID-19 dan perlindungan terhadap tenaga kesehatan. Diunduh dari : https://pogi.or.id/publish/wpcontent/uploads/2021/06/RevisiRekomendasi-POGI-utk-Bumil-denganCovid-19-.pdf (diakses 12 Juli 2021).

5. Siti H, Risnhukathulistiwi M, Wisnusanti SU. Manajemen Gizi Dalam Kondisi Bencana. Yogyakarta: Gadjah Mada University Press, 2018..

6. The management of nutrition in major emergencies. Geneva: World Health Organization, 2000.

7. World Health Organization, UNHCR, World Food Programme, UNICEF. Food and nutrition needs in emergencies. Geneva: World Health Organization.2004.

8. Pierre-Louis J. Food and nutrition in emergencies. Dalam The Johns Hopkins and Red Cross Red Crescent Public Health Guide in Emergencies.Edisi ke-2. Geneva : International Federation of Red Cross and Red Crescent Societies,2008. p. 443-85, 676.

9. Batalipu N, Sudirman S, Yani A. Manajemen penanggulangan gizi pasca bencana. INA-Rxiv.2019.

10. Widayatun, Fatoni Z. Permasalahan Kesehatan Dalam Kondisi Bencana : Peran Petugas Kesehatan Dan Partisipasi Masyarakat. Jurnal Kependudukan Indonesia.8(1).

11. Kementerian Kesehatan Republik Indonesia. Pedoman kegiatan gizi dalam penanggulangan bencana. 2012.

12. Health emergency and disaster risk management framework. Geneva: World Health Organization, 2019. Diunduh dari: https://www.who.int/ (diakses 12 Juli 2021)

13. Wood L, Boruff B, Smith H. When disaster strikes.: How communities cope and adapt: a social capital perspective. Dalam : Johnson C. Social Capital: Theory. Measurement and Outcomes. Nova Science Publishers, Inc. 2013. hal 143-69.

14. KoÇak H. The Role of Disaster Medicine in Disaster Management and Preparedness. Integrating Disaster Science and Management. 2018. hal 423-32.

15. Pourhosseini SS, Ardalan A, Mehrolhassani MH. Key Aspects of Providing Healthcare Services in Disaster Response Stage. Iran J Public Health. 2015;44(1):111-8. 
16. Wisner B, Adams J. Environmental health in emergencies and disasters : A practical guide. Geneva: World Health Organization; 2002.

17. Public Health England. Health emergency and disaster risk management : Nutrition. health emergency and disaster. England: World Health Organization. 2017.

18. Kementerian Kesehatan Republik Indonesia. Riset Kesehatan Dasar 2018. Diunduh dari : https://www.litbang.kemkes.go.id/(diakses 18 Juli 2021)

19. Lathifah N, Sumarmi S. Related Factors with School Age Children's Iodine Status in Indonesia. Jurnal Berkala Epidemiologi. 2018;6(2).

20. Perhimpunan Dokter Spesialis Gizi Klinik
Indonesia. Panduan praktis penatalaksanaan nutrisi COVID-19. Versi 1, 2020. Diundur dari: https://covid19.go.id/ (diakses 14 Juli 2021)

21. Kementerian Kesehatan Republik Indonesia. Pedoman pelayanan gizi pada masa tanggap darurat COVID-19. 2020. Diundur dari: https://covid19.go.id/ (diakses 14 Juli 2021)

22. Kementerian Kesehatan Republik Indonesia. Protokol Tata Laksana Covid-19 Edisi 2. $2021 . \quad$ Diundur dari: https://promkes.kemkes.go.id/ (diakes 14 Juli 2021) 


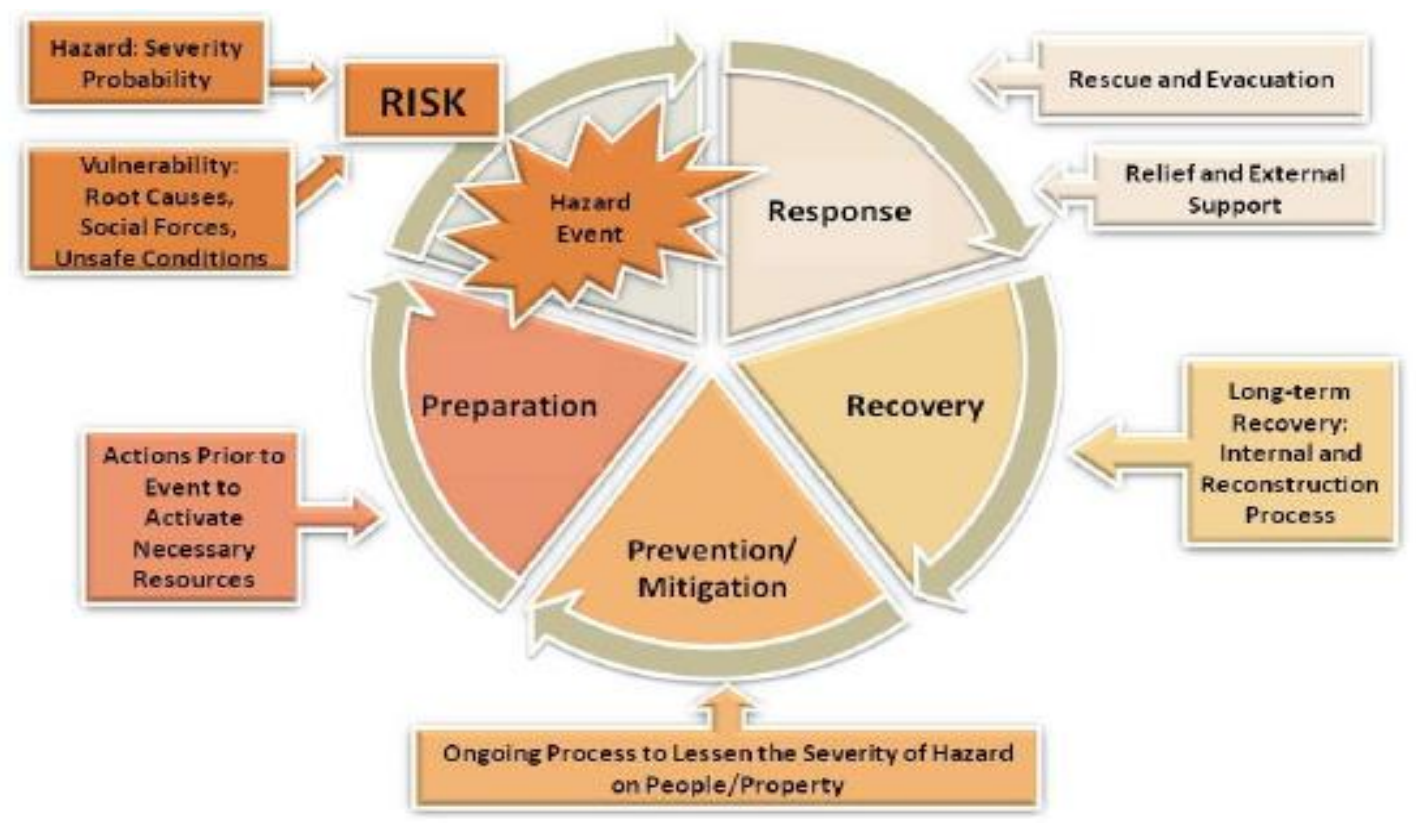

Gambar 1 Siklus manajemen bencana ${ }^{13}$

Tabel 1 Kebutuhan harian vitamin dan mineral untuk populasi yang membutuhkan bantuan makanan darurat. ${ }^{7}$

\begin{tabular}{cc}
\hline Vitamin/Mineral & Rekomendasi Harian \\
\hline Vitamin A & $500 \mu \mathrm{g}$ setara $1.666 \mathrm{IU}$ \\
Tiamin (B1) & $0.9 \mathrm{mg}$ \\
Riboflavin (B2) & $1.4 \mathrm{mg}$ \\
Niasin & $12 \mathrm{mg}$ \\
Asam folat & $160 \mu \mathrm{g}$ \\
Vitamin C & $28 \mathrm{mg}$ \\
Vitamin D & $3.8 \mu \mathrm{g}$ \\
Iron & $22 \mathrm{mg}$ \\
Iodin & $150 \mu \mathrm{g}$ \\
\hline
\end{tabular}

Tabel 2 Spesifikasi Makanan Fortifikasi. ${ }^{7}$

\begin{tabular}{ccc}
\hline Komoditas & Vitamin/Mineral & Kuantitas Fortivikasi \\
\hline Minyak sayur & Vitamin A & $30.000 \mathrm{IU} / \mathrm{kg}$ minyak atau \\
& Vitamin D & $9.000 \mu \mathrm{g}$ RE vitamin A per kg minyak \\
Garam & Iodin & $3.000 \mathrm{IU} / \mathrm{kg}$ minyak atau \\
& & $75 \mu \mathrm{g}$ RE vitamin D per kg minyak \\
& & $20-40 \mathrm{mg}$ iodin $/ \mathrm{kg}$ garam atau 33-66 \\
mg kalium \\
Tepung terigu dan & Iodin per kg garam \\
tepung jagung & Vitamin A & $>70$ th : 800 IU/hari \\
& Tiamin (B1) & 10.000 IU/hari \\
& Riboflavin (B2) & $4.4 \mathrm{mg}$ per kg tepung \\
& Niasin & $2.6 \mathrm{mg}$ pr kg tepung \\
& Asam folat & $35 \mathrm{mg}$ per kg tepung \\
& Besi & $0.4 \mathrm{mg}$ per kg tepung \\
\end{tabular}


Tabel 3 Contoh ransum tahap I di Indonesia. ${ }^{11}$

\begin{tabular}{ccc}
\hline Bahan Makanan & Kebutuhan per hari (g) & Ukuran Rumah Tangga \\
\hline Biskuit & 100 & $10-12$ buah \\
Mie instant & 320 & 3 gelas (4 bungkus) \\
Sereal & 50 & 5 sdm (4 saset) \\
Blended food (MP-ASI) & 50 & 10 sdm \\
Susu balita (1-5 tahun) & 40 & $8 \mathrm{sdm}$ \\
Energi (kkal) & 2138 & \\
Protein (g) & 53 & \\
Lemak (g) & 40 & \\
\hline
\end{tabular}

Tabel 4 Contoh Menu Makanan Sehari Untuk Ibu Hamil dan Ibu Menyusui (2200 kkal). ${ }^{11}$

\begin{tabular}{ccccccc}
\hline Bahan Makanan & $\begin{array}{c}\text { Jumlah } \\
\text { porsi }(\mathbf{g})\end{array}$ & Pagi & $\begin{array}{c}\text { Selingan } \\
\text { Pagi }\end{array}$ & Siang & $\begin{array}{c}\text { Selingan } \\
\text { Sore }\end{array}$ & Malam \\
\hline $\begin{array}{c}\text { Nasi atau bahan } \\
\text { makanan penukar }\end{array}$ & $6 \mathrm{p}+1 \mathrm{p}$ & $1 \mathrm{p}+1 / 2 \mathrm{p}$ & $1 \mathrm{p}$ & $2 \mathrm{p}$ & $1 / 2 \mathrm{p}$ & $1.5 \mathrm{p}+1 / 2 \mathrm{p}$ \\
$\begin{array}{c}\text { Lauk hewabi atau bahan } \\
\text { makanan penukar }\end{array}$ & $3 \mathrm{p}$ & $1 \mathrm{p}$ & - & $1 \mathrm{p}$ & - & $1 \mathrm{p}$ \\
$\begin{array}{c}\text { Lauk nabati atau bahan } \\
\text { makanan penukar }\end{array}$ & $3 \mathrm{p}$ & $1 \mathrm{p}$ & - & $1 \mathrm{p}$ & - & $1 \mathrm{p}$ \\
$\begin{array}{c}\text { Sayur atau bahan } \\
\text { makanan penukar }\end{array}$ & $3 \mathrm{p}$ & $1 \mathrm{p}$ & - & $1 \mathrm{p}$ & - & $1 \mathrm{p}$ \\
$\begin{array}{c}\text { Buah atau bahan } \\
\text { makanan penukar }\end{array}$ & $4 \mathrm{p}$ & - & $1 \mathrm{p}$ & $1 \mathrm{p}$ & $1 \mathrm{p}$ & $1 \mathrm{p}$ \\
$\begin{array}{c}\text { Gula } \\
\text { Minyak }\end{array}$ & $2 \mathrm{p}$ & $1 \mathrm{p}$ & - & - & $1 \mathrm{p}$ & - \\
$\quad$ Susu & $5 \mathrm{p}$ & $1.5 \mathrm{p}$ & $1 \mathrm{p}$ & $1 \mathrm{p}$ & - & $1.5 \mathrm{p}$ \\
\hline
\end{tabular}

Keterangan : Ditambahkan 1 porsi nasi atau penukar pada makanan ibu menyusui dengan tambahan $1 / 2 \mathrm{p}$ pada makanan pagi dan $1 / 2 \mathrm{p}$ makan malam. 